\title{
RESPONSES OF TURKISH CONSUMERS TO PRODUCT RISK INFORMATION IN THE CONTEXT OF NEGATIVE EWOM
}

\author{
Ülfet IŞÇI ${ }^{*}$ Hakan KITAPÇI \\ Institute of Social Sciences, Gebze Technical University, Kocaeli, Turkey \\ Received 14 October 2019; accepted 25 April 2020
}

\begin{abstract}
This study explores the risk-based effects of negative electronic word-of-mouth (neWOM) perception (financial and performance risks) on electronic word-of-mouth (eWOM) credibility and purchase intention for promotion- and prevention-focused consumers. In this experimental study, a survey was conducted in which 344 people from Turkey participated. Automobiles were chosen as the subject of the survey because they are in the high-risk product category. The results from regression analysis show that the neWOM perception containing financial risk information plays a more significant role than the one containing performance risk in terms of the effect on eWOM credibility for both promotion- and prevention-focused consumers. Moreover, the neWOM containing performance risk has no effect on the eWOM credibility for promotion-focused consumers. When exposed to neWOM, the purchase intentions of both consumers are even more negatively affected by the neWOM information containing performance risk than the one with financial risk content. The results and future predictions are discussed.
\end{abstract}

Keywords: neWOM, regulatory focus theory, purchase intention, eWOM credibility, perceived risk, online complaint.

JEL Classification: M31, D91, C90, C12.

\section{Introduction}

Recent advances in digital communication technologies have made such technologies indispensable in our daily lives and have exerted a strong influence on interpersonal communication methods. This innovative development with technological and social components has created new communication opportunities for consumers and producers in market research (Kreutzer, 2015; Tropp, 2019). This situation has transformed the role of consumers from a passive position to an active regulatory role, whereby they can share information and experiences at any moment or affect the contents of the communication (Fine et al., 2017; Kreutzer, 2019). Thus, it has transformed the conventional word-of-mouth (WOM) regarding

*Corresponding author. E-mail: ulfetisci@gmail.com

Copyright (c) 2020 The Author(s). Published by Vilnius Tech Press

This is an Open Access article distributed under the terms of the Creative Commons Attribution License (http://creativecommons. org/licenses/by/4.0/), which permits unrestricted use, distribution, and reproduction in any medium, provided the original author and source are credited. 
products, services, and companies into electronic word-of-mouth (eWOM) communication (Dellarocas, 2003; Hennig-Thurau et al., 2004; Babic-Rosario et al., 2020).

On the one hand eWOM eases the search of information about products and services, but on the other hand, it complicates the evaluation of this large amount of information from different anonymous sources (Steckel et al., 2005; Ku et al., 2012). Thus, consumers apply different criteria to filter and evaluate the information they obtain during decisionmaking processes, and eWOM credibility is among the most significant elements of these criteria (Cheung et al., 2009; Nan et al., 2017; Ismagilova et al., 2020; Thomas et al., 2019). Relevant studies suggest that negative reviews are more credible than positive ones (Chevalier \& Mayzlin, 2006; Lee \& Koo, 2012) and the effect of negative eWOM on the purchasing process is higher than the effect of positive eWOM (Park \& Lee, 2009; Beneke et al., 2016; Luo et al., 2018).

Comments, experiences, and complaints of consumers as eWOM do not only provide benefits for information search before the purchasing decision, but they also play an important role in the minimization of perceived risk (Hennig-Thurau \& Walsh, 2003; Hussain et al., 2017). However, during information search on online platforms, consumers may encounter negative comments from other consumers claiming risks of products and services. Within this scope, and unlike extant literature, this study categorizes online complaints by subject, constituting a type of neWOM information. The research has been conducted for the automobile sector; and two different categories are considered, namely, perceived financial and performance risks, which are the most effective risks in the sector (Jacoby \& Kaplan, 1972). The literature reveals that perceived financial and performance risks have greater impacts on consumers' purchase intention than other types of perceived risks do (Chang \& Tseng, 2013; Tian \& Ren, 2009).

The literature also shows that the effect created by eWOM is dependent on the characteristics of consumers who receive the information (Kim \& Lee, 2015). Accordingly, the regulatory focus theory (RFT) was considered, which affects the risky information-processing styles, as an individual character in this study (Förster et al., 2003). Within the last few years, RFT (Higgins, 1997) has been a popular point of interest for many consumer researchers since it is a strong predictor of how consumers respond to marketing communication and make decisions. This theory categorizes individuals into two different motivational orientations: promotion-focused consumers are oriented toward obtaining eager, risky, and positive outcomes; prevention-focused consumers are oriented toward careful, cautious, and negative outcomes, and avoid losses (Higgins \& Spiegel, 2004).

Previous studies suggest that both prevention-focused consumers with regulatory fit and promotion-focused consumers with regulatory non-fit show less purchase intention when exposed to negative reviews (Hsu et al., 2017). Likewise, they suggest that promotion- and prevention-focused consumers often make negative purchase decisions for new products when the risk is salient (Herzenstein et al., 2007). Considering the findings in the literature, this study suggests that being exposed to neWOM information that emphasizes different types of risks negatively affects the purchase intention of both promotion- and preventionfocused consumers. Besides, the study here shows that which types of risks in neWOM perception are more distinctive in these two groups. 
Studies suggest that a message that has a consistent regulatory focus with consumers' goals (regulatory fit) has a higher level of persuasiveness than a message whose regulatory focus is inconsistent (regulatory non-fit) (Camacho et al., 2003; Lee \& Aaker, 2004; Zhang et al., 2010). The results of these studies consider the regulatory fit as a foundation for eWOM credibility due to its level of persuasiveness. According to the findings in the literature, eWOM is considered more credible when prevention-focused consumers are exposed to neWOM information emphasizing different types of risk (regulatory fit), but it is unknown which risk components make neWOM more credible. Likewise, eWOM is estimated to be less credible when promotion-focused consumers are exposed to neWOM containing different risks (regulatory non-fit); however, it is not clear which types of risks will make the effect of neWOM perception more significant on eWOM credibility. Considering these viewpoints, here it is shown that what type of risk associated with neWOM perception has more effect on eWOM credibility and purchase intention in the context of promotion- and preventionfocused consumers of automobile products in Turkey.

The paper is structured as follows. Section 1 reviews the related literature, describes hypotheses and specifies the research models. Section 2 describes research design, presents data and empirical methods. The analysis results are presented in Section 3. Research discussion outlined in Section 4. Finally, the conclusions, research limitations and the recommendations for future research of the paper are presented in the conclusions.

\section{Literature review}

This literature review is about negative eWOM, eWOM credibility, purchase intention and regulatory focus theory. It covers the development of conceptual research models and the hypotheses.

\subsection{Negative electronic word-of-mouth}

According to Hennig-Thurau et al. (2004), e-WOM communication is "any positive or negative statement made by potential, actual, or former customers about a product or company, which is made available to a multitude of people and institutions via the Internet". In eWOM, information is globally transferred via the Internet, and it can be positive, negative, or neutral. Due to the nature of the research object, the present study only focuses on the negative statements in eWOM communication. neWOM is nothing more than the complaint behavior of customers (Strauss \& Seidel, 2007; Himmelreich, 2019) and in this sense, the term is formally defined as the negative feedback about products or services or a brand that is posted and viewed on online forums (Wetzer et al., 2007). Studies in the field of neWOM state negative messages have strong impacts on consumer purchase intention (Chevalier \& Mayzlin, 2006; Shihab \& Putri, 2019) and on consumer attitude toward a product (Lis \& Fischer, 2020). Consumers initially search for neWOM to mitigate risk factors and cognitive dissonance because perceived risks have a big impact on consumer behaviors (Schöler, 2010). 


\subsection{Electronic word-of-mouth credibility}

eWOM consists of a large amount of unfiltered information about products and/or services sourced by anonymous people around the world. This extensive information increases the risk perception of consumers (Franagin et al., 2014) while complicating the determination of the credibility of other participants of online portals and the information shared by them (Cheung et al., 2009). In this sense, eWOM credibility can be defined as "the extent to which the receiver perceives the online information as believable, factual and unbiased" (Cheung et al., 2009) and further explained as a strong predictor of other actions taken by the readers, such as recommendation or willingness to adopt the viewpoint of the information they receive.

Generally, individuals tend to build a relatively strong trust in the information received through eWOM when they think that the information is credible (Park et al., 2011; Thomas et al., 2019). If a receiver thinks that online reviews have lower credibility, he or she often prefers resisting eWOM's persuasiveness. Therefore, consumers' thoughts about message credibility are highly important and effective in terms of acceptance of the online messages (Lee \& Koo, 2012).

\subsection{Purchase intention}

For consumers, eWOM is an important source to obtain information about the quality of products or services before purchases. In this regard, consumers tend to perform a multidirectional information search in each stage of the purchasing process and consider not only positive comments about products or services, but also negative comments. Therefore, consumers rationalize their own purchasing behaviors based on the extensive information available. The literature on eWOM suggests that the impact of negative reviews on the purchase intention is bigger than that of positive reviews (Park \& Lee, 2009) and perceived risk also has a significant impact on the purchase intention of consumers (Lin \& Fang, 2006; Tian \& Ren, 2009; Ali et al., 2010).

\subsection{Regulatory focus theory}

On the basis of regulatory focus theory (Higgins, 1997), people act on two separate motivational orientations (i.e., promotion- and prevention-focused) to achieve their goals based on an individual factor called regulatory focus. Individuals with different regulatory foci often look for or prefer different information about the same situation and adopt different strategies to achieve their goals. Promotion-focused individuals search for the existence or absence of positive results of a specific event, while prevention-focused people adjust their responses based on the existence or absence of negative results. As they are generally impulsive and careless people, promotion-focused consumers tend to make mistakes by taking high risks, which is explained as the risky bias. However, prevention-focused people work carefully and have a relatively slow work style called the conservative bias (Higgins \& Spiegel, 2004). People with different regulatory focus orientations have different risk perceptions (Lee \& Aaker, 2004; Van Noort et al., 2008; Hamstra et al., 2011) just as the processing and impacts of information differ in both focus groups (Higgins, 1997). 
Regulatory focus results from a chronic characteristic (personal disposition) and a situational (context-induced) variable (Higgins, 1997). Chronic regulatory focus takes place during the process of growth that is a kind of long-term regulatory focus. Situational regulatory focus also called short-term regulatory focus is a kind of personality tendency induced by specific situation and task frame information.

Studies in the marketing literature show that a product is a regulatory fit if it has the characteristics that the consumer looks for; in other words, when its regulatory focus is consistent with the consumer's expectation (Aaker \& Lee, 2006; Avnet \& Higgins, 2006; Lin \& Shen, 2012). Because the regulatory fit situation occurs when a product is consistent with the regulatory orientation of the consumer, the regulatory fit plays a significant role in the product assessment processes under marketing.

\subsection{Models and hypotheses}

Individuals tend to use approaching (promotion focus) or avoidance strategies (prevention focus) based on their regulatory focus (Higgins, 1997). That is, different regulatory mode orientations contain different concerns as well as information processing styles (Kumashiro et al., 2007). So, it is predicted that responses of consumers to neWOM contents containing different types of risks will not be the same. Within this context, the motivational orientations of consumers, as individual characteristics, can affect the processing of negative contents with risk components. Thus, consumers with different regulatory foci are expected to give different responses to neWOM information containing financial and performance risks.

Previous studies show that negative reviews are more credible compared with positive reviews (Chevalier \& Mayzlin, 2006; Lee \& Koo, 2012). Besides existing studies reveal that a message with a consistent regulatory focus with the consumer's goal (regulatory fit) has higher persuasiveness than an inconsistent message (regulatory non-fit) (Camacho et al., 2003; Lee \& Aaker, 2004; Zhang et al., 2010). The results of these studies consider the regulatory fit as a foundation for eWOM credibility due to its level of persuasiveness. Based on this theoretical background, both promotion- and prevention-focused consumers are expected to find a negative message credible where they are exposed to two different types of neWOM containing performance and financial risks.

However, no particular study has been conducted to explain which type of negative message with performance and financial risk components is considered more credible in the automobile sector by prevention- and promotion-focused consumers. Therefore, the effect of risk-containing neWOM on eWOM credibility has not been clearly identified. Accordingly, the following hypotheses are developed:

H1a. The neWOM perception containing performance risk has an effect on the eWOM credibility in promotion-focused consumers.

H1b. The neWOM perception containing financial risk has an effect on the eWOM credibility in promotion-focused consumers.

$\mathrm{H} 2 \mathrm{a}$. The neWOM perception containing performance risk has an effect on the eWOM credibility in prevention-focused consumers.

$\mathrm{H} 2 \mathrm{~b}$. The neWOM perception containing financial risk has an effect on the eWOM credibility in prevention-focused consumers. 
Previous studies suggest that perceived risk has an effect on consumer purchase intention (Lin \& Fang, 2006; Tian \& Ren, 2009; Ali et al., 2010). As mentioned above, neWOM perceptions with different types of risks do not have the same effect on consumers. Therefore, the effect of neWOM information, which contains different types of risks, is also subject to change based on the regulatory focus. As the literature shows, prevention-focused individuals have a more negative approach toward negative situations, compared with promotionfocused consumers (Halamish et al., 2007). The study shows that, both prevention-focused consumers with regulatory fit and promotion-focused consumers with regulatory non-fit show less purchase intention after being exposed to negative reviews (Hsu et al., 2017). In addition, promotion- and prevention-focused consumers often make negative purchasing decisions for new products if the risk is salient (Herzenstein et al., 2007).

In this respect, it is predicted that the purchase intention of promotion and preventionfocused consumers are negatively affected by the neWOM information to which they are exposed. Furthermore, the study reveals the type of risk component to which prevention- and promotion-focused consumers are more sensitive and how it can affect the purchase intention. Therefore, the following hypotheses are developed:

$\mathrm{H} 3 \mathrm{a}$. The neWOM perception containing performance risk has a negative effect on the purchase intention of promotion-focused consumers.

$\mathrm{H} 3 \mathrm{~b}$. The neWOM perception containing financial risk has a negative effect on the purchase intention of promotion-focused consumers.

H4a. The neWOM perception containing performance risk has a negative effect on the purchase intention of prevention-focused consumers.

$\mathrm{H} 4 \mathrm{~b}$. The neWOM perception containing financial risk has a negative effect on the purchase intention of prevention-focused consumers.

Figure 1a and Figure $1 \mathrm{~b}$ show the conceptual research models of this study.

a)

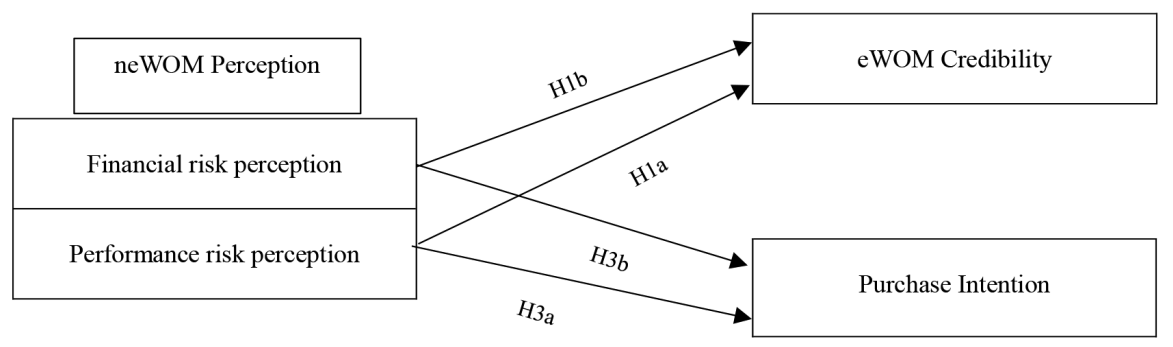

b)

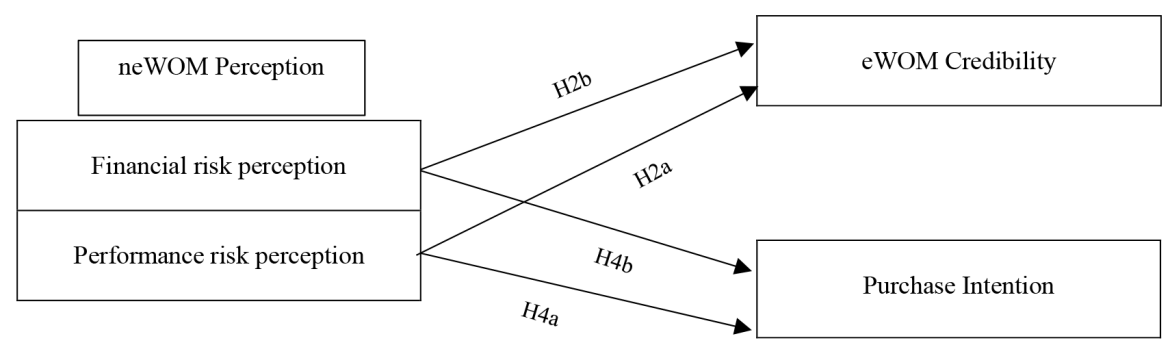

Figure 1. Research model for: $\mathrm{a}$ - promotion-focused consumers; $\mathrm{b}$ - prevention-focused consumers 


\section{Methodology}

The methodology that is used in this study is explained in details below.

\subsection{Research design}

This study was applied to 344 graduate students using an experimental design. The neWOM message contents were manipulated as an independent variable. This manipulations are based on performance risk- and financial risk-focused scenarios. Both eWOM credibility and purchase intention are dependent variables. Table 1 presents the descriptive statistics of variables.

Table 1. Descriptive statistics

\begin{tabular}{|l|c|c|c|}
\hline & N & Mean & Std. Deviation \\
\hline Performance risk & 344 & 4.437 & 0.752 \\
\hline eWOM credibility $^{\star}$ & 344 & 2.979 & 1.082 \\
\hline Purchase intention $^{*}$ & 344 & 1.507 & 0.767 \\
\hline Financial risk & 344 & 4.124 & 0.737 \\
\hline eWOM credibility $^{*}$ & 344 & 3.272 & 1.057 \\
\hline Purchase intention $^{* *}$ & 344 & 1.576 & 0.765 \\
\hline
\end{tabular}

Notes: ${ }^{*}$ effect of performance risk perception, ${ }^{*}$ effect of financial risk perception.

\subsection{Experimental product}

The automobile sector was chosen as target experimental product group because it has the largest perceived risk for each relevant risk component (Jacoby \& Kaplan, 1972). Moreover, automobiles are scarcely purchased and expensive products, requiring high maintenance costs. Therefore, this product group causes high levels of perceived risk and requires an intensive preliminary information search process.

\subsection{Negative electronic word-of-mouth as a form of complaint}

Certain studies consider neWOM as a new type of consumer complaint behavior (CCB) (Strauss \& Seidel, 2007; Himmelreich, 2019) and accordingly emphasize its significance. The popularization of the Internet has led to the emergence of complaint websites, and thus allowed mass consumers to easily access negative information about products, services, or companies. Therefore, many potential consumers make decisions based on these messages. Accordingly, in this paper, the concept of neWOM was obtained from the complaints posted on complaint websites (sikayetvar.com, sikayetim.com, sikayet.com). The scenarios given to the participants were prepared by collecting consumer complaints about automobiles from complaint websites and manipulating them according to the financial and performance risk content.

\subsection{Procedure and participants}

This empirical study was conducted in a classroom environment where each participant was asked to fill out the same three-page survey. Each survey included a regulatory focus 
questionnaire (RFQ) that measured the chronic regulatory orientation of the participants in order to place them under prevention- or promotion-focused consumer categories. Next, the participants were asked to read the neWOM information comprising two different scenarios that support performance and financial risks of automobiles. In these scenarios, the impact of participants' current perception about automobile brands was eliminated by excluding specific brand names in the neWOM, considering that neWOM has a positive effect on brands with lower levels of awareness (Berger et al., 2010).

Every survey participant was asked to read a scenario on performance risk and immediately answer the questions thereof. Next, the same participant was asked to read another scenario about financial risk and answer questions thereof. In both scenarios, the questions had three layers: perceived risk, eWOM credibility, and purchase intention. Questions addressed in the following section were about demographic characteristics, car driving patterns of the participants, and Internet use.

The study was applied to 344 graduate students to test the validity of the hypotheses. The subject group of this study consists of students since they are closely associated with eWOM and they often perform information searches before purchasing a product. In addition, participants were chosen from active car owners and potential customers. Male participants constituted the 58 percent, the remaining 42 percent were female participants.

\subsection{Measurement}

The measurements in this study were conducted using a 5-point Likert scale $(1=$ strongly disagree to 5 = strongly agree). Performance and financial risks were measured with three items adapted from Stone and Mason (1995); eWOM credibility was measured with five items adapted from Cheung et al. (2009) and Prendergast et al. (2010); and purchase intention was measured with four items adapted from Coyle and Thorson (2001) and Prendergast et al. (2010). Further, scale items to measure the chronic regulatory focus with eleven items were adapted from Higgins et al. (2001), which were measured with a 5-point Likert scale $(1=$ never to $5=$ very often). The original English measurements are translated into Turkish, and then they were translated back into English. After comparison the final form of measurements are decided.

Data analysis was conducted using SPSS 25.0 software. A factor analysis was conducted to identify components for independent and dependent variables using the principal component analysis in the context of each risk-based neWOM perception. The analysis categorized 12 items into 3 components for the performance risk-based neWOM perception. The rotated component matrix is shown in Table 2 . The reliability results of each variable show that the Cronbach alpha value for performance risk is 0.732 . The values for dependent variables such as eWOM credibility and purchase intention are 0.942 and 0.918 , respectively.

For the financial risk-based neWOM perception, the factor analysis categorized 12 items into 3 components. The rotated component matrix is shown in Table 3. As a result of reliability analysis, the Cronbach alpha value for financial risk is 0.782 . The values for dependent variables such as eWOM credibility and purchase intention are 0.737 and 0.933 , respectively. A reliability coefficient above 0.70 is preferable (Vellis, 2003). Therefore, in this study, the Cronbach alpha for all variable measurements are reliable. 
Table 2. Factor analysis results for performance risk-based neWOM perception

\begin{tabular}{|c|c|c|c|}
\hline & \multicolumn{3}{|c|}{ Component } \\
\hline & 1 & 2 & 3 \\
\hline Performance risk 1 & & & 0.863 \\
\hline Performance risk 2 & & & 0.631 \\
\hline Performance risk 3 & & & 0.867 \\
\hline eWOM credibility 1 & 0.876 & & \\
\hline eWOM credibility 2 & 0.928 & & \\
\hline eWOM credibility 3 & 0.928 & & \\
\hline eWOM credibility 4 & 0.869 & & \\
\hline eWOM credibility 5 & 0.902 & & \\
\hline Purchase Intention 1 & & 0.876 & \\
\hline Purchase Intention 2 & & 0.895 & \\
\hline Purchase Intention 3 & & 0.887 & \\
\hline Purchase Intention 4 & & 0.873 & \\
\hline
\end{tabular}

Table 3. Factor analysis results for financial risk-based neWOM perception

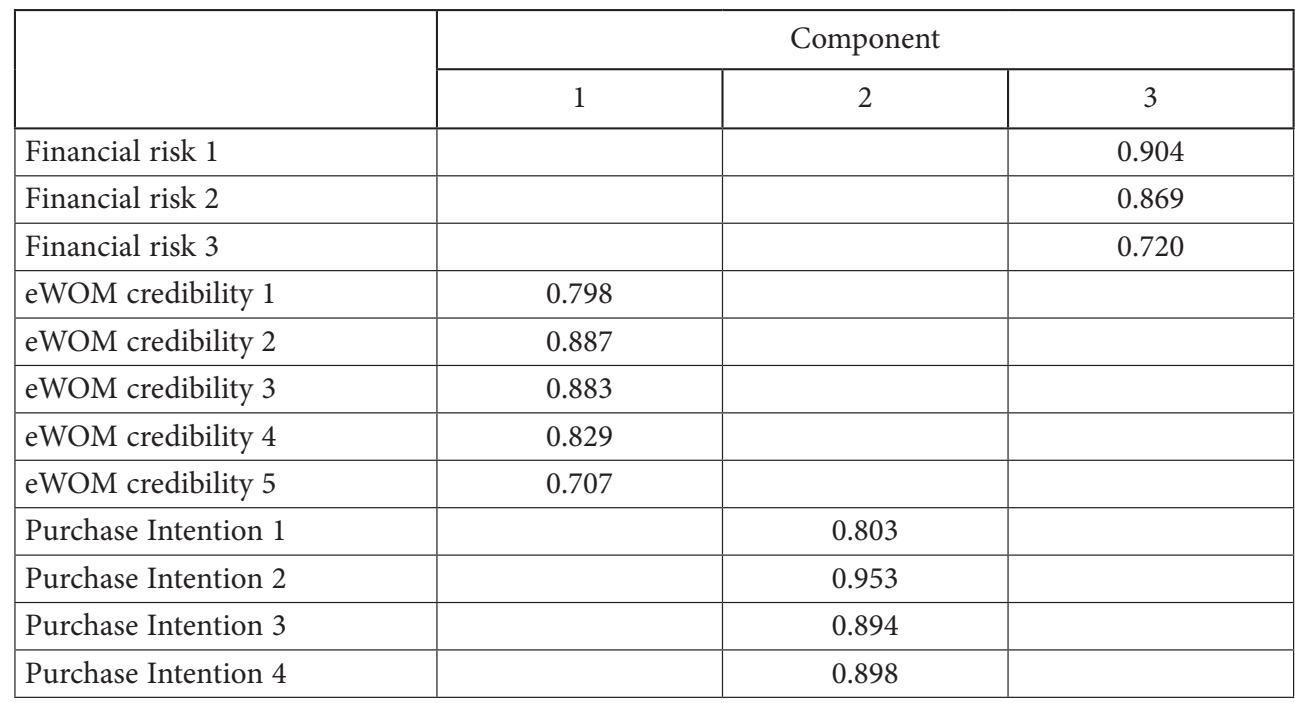

\subsubsection{Chronic regulatory focus}

The chronic regulatory focus scores of the participants were measured to determine the chronic regulatory orientations. A promotion score was created by calculating the average ratings that participants obtained from the promotion items of the RFQ scale, and a prevention score was developed considering the average result of the prevention items. Then, the prevention score of the participants was subtracted from the promotion score and a regulatory focus score was calculated. Participants were categorized as promotion- or preventionfocused based on a median split of the regulatory focus score (Cesario et al., 2004; Hong \& 
Lee, 2008). In this study, members of the promotion focused group is represented as ' $N=$ 184 ' and the number of the prevention-focused group is explained as ' $N=160$ '.

\subsubsection{Hypothesis testing}

The study analyzes the effect of neWOM on reactions/responses of Turkish promotion- and prevention-focused consumers toward purchase intention and eWOM credibility through scenarios supporting performance and financial risks. Therefore, regression analyses were performed to test the proposed hypotheses.

\section{Results}

The effects of eWOM credibility and purchase intention in promotion and prevention focused consumers are explained by regression analysis.

\subsection{Effects of electronic word-of-mouth credibility and purchase intention in promotion-focused consumers}

The effect of financial and performance risk-based neWOM perceptions of promotionfocused participants was analyzed using regression analysis. The results of the regression analysis show that the financial risk perception $(R 2=0.290, F=107.101, p=0.000)$ explains 29 percent of eWOM credibility in promotion-focused participants. As shown in Table 4, risk-based neWOM perceptions of promotion-focused participants are different from each other. The neWOM perception containing performance risk does not affect the eWOM credibility. Thus, hypothesis Hla is not supported; however, hypothesis H1b is supported, as only the perception of financial risk containing neWOM has an effect on eWOM credibility $(\beta=$ $0.539, p<0.01)$.

To test hypotheses $\mathrm{H} 3 \mathrm{a}$ and $\mathrm{H} 3 \mathrm{~b}$, an analysis was performed to examine the effect of neWOM perception of promotion-focused participants on the purchase intention, which depends on the financial or performance risk content. According to the regression analysis, 9 percent of the purchase intention depends on the performance risk perception $(R 2=0.094$, $F=12.17, p=0.00)$, while only 3 percent is explained by the financial risk perception $(R 2=$ $0.034, F=9.162, p=0.003)$.

According to Table 4, the financial and performance risk perception of promotionfocused participants has a significant effect on purchase intention. Thus, hypotheses H3a and $\mathrm{H} 3 \mathrm{~b}$ are supported. However, this effect on the purchase intention depends on the type of risk. That is, as evident in Table 4, the performance risk perception has a bigger negative effect $(\beta=-0.307, p<0.01)$ on the purchase intention compared with the financial risk perception $(\beta=-0.184, p<0.01)$. Therefore, it is concluded that the performance risk perception plays a more significant role in the purchase intention of promotion-focused participants toward automobiles than the financial risk perception. The results of regression analysis suggest that eWOM is more credible in promotion-focused participants who are exposed to financial risk contents, while the performance risk is more significant in terms of the purchase intention. 
Table 4. Regression analysis results for promotion-focused consumers

\begin{tabular}{|l|l|c|c|c|c|}
\hline Dependent variables & \multicolumn{1}{|c|}{ Predictors } & $\mathrm{F}$ & $R^{2}$ & B (Beta) & Sig. \\
\hline \multirow{2}{*}{ eWOM credibility } & Performance risk perception & \multicolumn{5}{|c|}{ N/A } \\
\cline { 2 - 7 } & Financial risk perception & 107.101 & 0.290 & 0.539 & $0.000^{*}$ \\
\hline \multirow{2}{*}{ Purchase intention } & Performance risk perception & 27.201 & 0.094 & -0.307 & $0.000^{* *}$ \\
\cline { 2 - 7 } & Financial risk perception & 9.162 & 0.034 & -0.184 & $0.003^{*}$ \\
\hline
\end{tabular}

Note: Significant at: ${ }^{\star} p<0.05,{ }^{*} p<0.01$; eWOM: electronic word-of-mouth.

\subsection{Effect of electronic word-of-mouth credibility and purchase intention in prevention-focused consumers}

According to the regression analysis conducted to determine the effect of prevention-focused participants' financial and performance risk-based neWOM perceptions on eWOM credibility, the financial risk perception explains 20 percent of the variance in eWOM credibility $(R 2=0.20, F=20.361, p=0.000)$, while the performance risk perception explains only 3 percent of it $(R 2=0.035, F=2.861, p=0.047)$. As shown in Table 5 , the financial risk perception $(\beta=0.455, p<0.01)$ has a bigger effect than the performance risk perception $(\beta=0.188$, $p<0.05)$ in prevention-focused participants in terms of eWOM credibility. Thus, hypotheses $\mathrm{H} 2 \mathrm{a}$ and $\mathrm{H} 2 \mathrm{~b}$ are supported.

Further, according to the regression analysis on the effect of financial and performance risk-based neWOM perceptions of the prevention-focused participants on the purchase intention, the performance risk perception explains 21 percent of the purchase intention in prevention-focused participants $(R 2=0.215, F=21.370, p=0.000)$, while the financial risk perception explains 6 percent of it $(R 2=0.062, F=5.178, p=0.009)$.

According to Table 5, neWOM perceptions containing different types of risks have different effects on the purchase intention of the prevention-focused participants. That is, the performance risk perception has a bigger negative effect $(\beta=-0.464, p<0.01)$ on the purchase intention compared with the financial risk perception $(B=-0.249, p<0.05)$. Thus, hypotheses $\mathrm{H} 4 \mathrm{a}$ and $\mathrm{H} 4 \mathrm{~b}$ are supported. Hence, it can be concluded that the performance risk perception plays a more significant role in purchase intention of prevention-focused participants toward automobiles than the financial risk perception. The results also show that prevention-focused participants find eWOM to be more credible when exposed to neWOM information containing financial risk, but their purchase intention is less affected compared with the neWOM perception containing performance risk.

Table 5. Regression analysis results for prevention-focused consumers

\begin{tabular}{|l|l|c|c|c|c|}
\hline Dependent variables & \multicolumn{1}{|c|}{ Predictors } & $\mathrm{F}$ & $\mathrm{R}^{2}$ & $\mathrm{~B}$ (Beta) & Sig. \\
\hline \multirow{2}{*}{ eWOM credibility } & Performance risk perception & 2.861 & 0.035 & 0.188 & $0.047^{\star}$ \\
\cline { 2 - 6 } & Financial risk perception & 20.361 & 0.207 & 0.455 & $0.000^{\star}$ \\
\hline \multirow{2}{*}{ Purchase intention } & Performance risk perception & 21.370 & 0.215 & -0.464 & $0.000^{* *}$ \\
\cline { 2 - 7 } & Financial risk perception & 5.178 & 0.062 & -0.249 & $0.009^{*}$ \\
\hline
\end{tabular}

Note: Significant at: ${ }^{*} p<0.05,{ }^{* *} p<0.01$; eWOM: electronic word-of-mouth. 
According to the results which are presented, the neWOM perception toward automobiles, which contains performance risk information, has a significantly negative effect on the purchase intention of both promotion- and prevention-focused participants. In terms of eWOM credibility, neWOM perception with financial risk has a positive effect on both groups. Therefore, hypotheses H1b, H2a, H2b, H3a, H3b, H4a, and H4b are supported.

\section{Discussion}

With the advance of digital technologies, consumers are faced with massive amounts of information about products or services. Thus, eWOM is an important online information source that guides consumers during purchasing processes (Jiménez \& Mendoza, 2013). Yet, the impact of eWOM on consumers may vary depending on individual characteristics. Within this framework, RFT has gained the interest of many consumer researchers in marketing since it is a strong predictor of how consumers respond to marketing communication and make decisions. Based on motivational orientations, this theory divides consumers into two groups, namely, promotion focused consumers and prevention-focused consumers (Higgins, 1997). This study aimed to analyze the effects of (financial and performance) risk-containing neWOM perception on eWOM credibility and purchase intention while considering the RFT factor.

The findings of this paper show that only financial risk containing neWOM perception has an effect on eWOM credibility in the promotion-focused consumer group, while the performance risk containing neWOM perception has no significant effect. Likewise, neWOM perception containing financial risk information plays a more significant role than the performance risk in terms of the effect on eWOM credibility among prevention-focused consumers. Therefore, it is concluded that neWOM with financial risk affects eWOM credibility for both promotion- and prevention-based consumers. This means that both consumers consider financial risk containing neWOM information more credible. According to previous studies, negative online reviews are considered more credible than positive ones (Chevalier \& Mayzlin, 2006; Lee \& Koo, 2012). Besides, existing studies reveal that a message with a consistent regulatory focus with the consumer's goal (regulatory fit) has higher persuasiveness than an inconsistent message (regulatory non-fit) (Camacho et al., 2003; Lee \& Aaker, 2004; Zhang et al., 2010). The results of these studies consider the regulatory fit as a foundation for eWOM credibility due to its level of persuasiveness. According to the results, in the cases of both regulatory fit and non-fit, eWOM is found more credible. But, this is not the case for the promotion focus consumers when neWOM involves performance risk. In this context, this study is consistent with the literature, with the exception of the aforementioned new finding. Another contribution of the study is that perception of neWOM, which involves financial risk, on eWOM credibility is more important for both cases.

When exposed to negative eWOM, the purchase intention of both promotion- and prevention-focused consumers are affected more by neWOM information containing performance risk than the one with financial risk content. Thus, performance risk containing neWOM perception has a more negative effect on consumers' purchase intention. Extant literature suggests that promotion- and prevention-focused consumers often make negative 
purchasing decisions for new products if the risk is salient (Herzenstein et al., 2007). Moreover, Hsu et al. (2017) state that both prevention-focused consumers with regulatory fit and promotion-focused consumers with regulatory non-fit show less purchase intention after being exposed to negative reviews. Therefore, the results are in line with extant literature and contribute to the field by explaining the effect of neWOM on the purchase intention based on the risk content.

\section{Conclusions}

In the literature, studies on eWOM information focus on how online reviews affect message credibility and acceptance. So far, review valence (positive and negative messages) has been the most studied research subject in the field. Certain studies focus on the relationship between the regulatory foci of consumers and the present risks. On the other hand, some other studies use RFT to perform the consistency between the regulatory focus and message framing. But little research has focused on the role of regulatory focus in negative online reviews. Therefore, instead of considering both positive and negative reviews, which is a popular approach in the literature, this study focused only on negative reviews in terms of performance and financial risk. Up to this point, no study in the literature has dealt with the effects of neWOM, containing performance and financial risks, by using RFT.

In this research, addressing the gap, which is mentioned above, and using RFT and neWOM as a more comprehensive theoretical framework, this paper examined the risk-based effects of negative electronic word-of-mouth (neWOM) perception (with financial and performance risks) on eWOM credibility and purchase intention for promotion- and prevention-focused consumers. Besides, this is the first study in the context of regulatory focus theory that investigates the effect of neWOM containing financial and performance risks on eWOM credibility and purchase intention in the automobile sector in Turkey.

This research contributes to the literature in several ways. The findings are generally consistent within regulatory fit studies. But some interesting differences were observed. For example; the perception of neWOM, which includes financial risk, affects eWOM credibility more, whereas the perception of neWOM, which includes performance risk, affects the purchase intention more adversely in the automobile sector. This is the case for both prevention- and promotion-focused consumers. The similar findings in both groups may be due to the product itself. Because automobiles are in high risk product group and the perceived risk is high.

Although risk tendencies are different, the types of the risk (financial and performance) are same for both prevention and promotion-focused consumers. These types of risks are deterministics on eWOM credibility and purchase intention. In this context the results of this research are important and they deserve attention.

This study is subject to certain limitations. First, only automobile products were used in the study since the risk level of this product group is relatively high. However, future studies may cover different product groups and identify other effects of product groups. Second, we organized the neWOM information on automobile products under two risk groups, financial and performance risks, because they have been the most popular subject in relevant studies 
thus far. They also have a closer relationship with the purchasing decision than other risks do. However, other types of risks prevalent in the automobile sector could be the focus of future studies. In this study, the chronic regulatory focus is emphasized, rather than the situational regulatory focus. Another limitation is that the sample which is used in this research is restricted to Turkey. In future research, the effect of neWOM could be studied and compared across cultures with different dimensions based on Higgins's regulatory focus theory.

\section{References}

Aaker, J. L., \& Lee, A. Y. (2006). Understanding regulatory fit. Journal of Marketing Research, 43(1), 15-19. https://doi.org/10.1509/jmkr.43.1.15

Ali, H. A., Farhad, G., \& Nooshin, G. T. (2010). A study of the role of perceived risk and user characteristics in Internet purchase intention. World Academy of Science, 66, 43-47.

Avnet, T., \& Higgins, E. T. (2006). How regulatory fit affects value in consumer choices and opinions. Journal of Marketing Research, 43, 1-10. https://doi.org/10.1509/jmkr.43.1.1

Babic-Rosario, A., Sotgiu, F., \& de Valck, K. (2020). Conceptualizing the electronic word-of-mouth process. What we know and need to know about eWOM creation, exposure, and evaluation. Journal of the Academy of Marketing Science, 48, 422-448. https://doi.org/10.1007/s11747-019-00706-1

Beneke, J., de Sousa, S., Mbuyu, M., \& Wickham, B. (2016). The effect of negative online customer reviews on brand equity and purchase intention of consumer electronics in South Africa. The International Review of Retail, Distribution and Consumer Research, 26(2), 171-201. https://doi.org/10.1080/09593969.2015.1068828

Berger, J., Sorensen, A. T., \& Rasmussen, S. J. (2010). Positive effects of negative publicity: When negative reviews increase sales. Marketing Science, 29(5), 815-827. https://doi.org/10.1287/mksc.1090.0557

Camacho, C. J., Higgins, E. T., \& Luger, L. (2003). Moral value transfer from regulatory fit: 'What feels right is right' and 'what feels wrong is wrong'. Journal of Personality and Social Psychology, 84, 498-510. https://doi.org/10.1037/0022-3514.84.3.498

Cesario, J., Grant, H., \& Higgins, E. T. (2004). Regulatory fit and persuasion: transfer from 'feeling right'. Journal of Personality and Social Psychology, 86, 388-404. https://doi.org/10.1037/0022-3514.86.3.388

Chang, E. C., \& Tseng, Y. F. (2013). Research note: e-store image, perceived value and perceived risk. Journal of Business Research, 66, 864-870. https://doi.org/10.1016/j.jbusres.2011.06.012

Cheung, M., Luo, C. S., \& Chen, H. (2009). Credibility of electronic word-of-mouth: informational and normative determinants of on-line consumer recommendations. International Journal of Electronic Commerce, 14(3), 9-38. https://doi.org/10.2753/JEC1086-4415130402

Chevalier, J. A., \& Mayzlin, D. (2006). The effect of word of mouth on sales: online book reviews. Journal of Marketing Research, 38(3), 345-354. https://doi.org/10.1509/jmkr.43.3.345

Coyle, J. R., \& Thorson, E. (2001). The effects of progressive levels of interactivity and vividness in web marketing sites. Journal of Advertising, 30, 65-77. https://doi.org/10.1080/00913367.2001.10673646

Dellarocas, C. (2003). The digitization of word of mouth: Promise and challenges of online feedback mechanism. Management Science, 49(10), 1407-1424. https://doi.org/10.1287/mnsc.49.10.1407.17308

Fine, M. B., Gironda, J., \& Petrescu, M. (2017). Prosumer motivations for electronic word-of mouth communication behaviors. Journal of Hospitality and Tourism Technology, 8(2), 280-295. https://doi.org/10.1108/JHTT-09-2016-0048

Förster, J., Higgins, E. T., \& Bianco, A. T. (2003). Speed accuracy decisions in task performance: built in trade-off or separate strategic concerns? Organizational Behavior and Human Decision Processes, 90, 148-164. https://doi.org/10.1016/S0749-5978(02)00509-5 
Franagin, A., Metzger, M., Pure, R., Markov, A., \& Hartsel, E. (2014). Mitigating risk in ecommerce transactions: perceptions of information credibility and the role of user generated ratings in product quality and purchase intention. Electronic Commerce Research, 14(1), 1-23.

https://doi.org/10.1007/s10660-014-9139-2

Halamish, V., Liberman, N., Higgins, E. T., \& Idson, L. C. (2007). Regulatory focus effects on discounting over uncertainty for losses vs. gains. Journal of Economic Psychology, 29(5), 654-666. https://doi.org/10.1016/j.joep.2007.09.002

Hamstra, M. R. W., Bolderdijk, J. W., \& Veldstra, J. L. (2011). Everyday risk taking as a function of regulatory focus. Journal of Research in Personality, 45(1), 134-137. https://doi.org/10.1016/j.jrp.2010.11.017

Hennig-Thurau, T., \& Walsh, G. (2003). Electronic word-of-mouth: motives for and consequences of reading customer articulations on the Internet. International Journal of Electronic Commerce, 8(2), 51-74. https://doi.org/10.1080/10864415.2003.11044293

Hennig-Thurau, T., Gwinner, K. P., Walsh, G., \& Gremler, D. D. (2004). Electronic word-of-mouth via consumer-opinion platforms: What motivates consumers to articulate themselves on the internet? Journal of Interactive Marketing, 18(1), 38-52. https://doi.org/10.1002/dir.10073

Herzenstein, M., Posavac, S. S., \& Brakus, J. J. (2007). Adoption of new and really new products: The effects of self-regulation systems and risk salience. Journal of Marketing Research, 44(2), 251-260. https://doi.org/10.1509/jmkr.44.2.251

Higgins, E. T. (1997). Beyond pleasure and pain. American Psychologist, 52(12), 1280-1300. https://doi.org/10.1037/0003-066X.52.12.1280

Higgins, E. T., Friedman, R. S., Harlow, R. E., Idson, L. C., Ayduk, O. N., \& Taylor, A. (2001). Achievement orientations from subjective histories of success: Promotion pride versus prevention pride. European Journal of Social Psychology, 31(1), 3-23. https://doi.org/10.1002/ejsp.27

Higgins, E. T., \& Spiegel, S. (2004). Promotion and prevention strategies for self-regulation: a motivated cognition perspective. In R. F. Baumeister \& K. D. Vohs (Eds.), Handbook of self-regulation (pp. 171-187). The Guilford Press.

Himmelreich, S. (2019). Digitale Unternehmenskritiker. Determinanten unternehmens- kritischer Kommentare im Internet. Springer. https://doi.org/10.1007/978-3-658-26747-6_5

Hong, J., \& Lee, A. Y. (2008). Be fit and be strong: mastering self-regulation through regulatory fit. Journal of Consumer Research, 34(5), 682-695. https://doi.org/10.1086/521902

Hsu, C.-L., Yu, L.-C., \& Chang, K.-C. (2017). Exploring the effects of online customer reviews, regulatory focus, and product type on purchase intention: Perceived justice as a moderator. Computers in Human Behavior, 69, 335-346. https://doi.org/10.1016/j.chb.2016.12.056

Hussain, S., Ahmed, W., Jafar, R. M., Rabnawaz, A., \& Jianzhou, Y. (2017). eWOM source credibility, perceived risk and food product customer's information adoption. Computers in Human Behavior, 66, 96-102. https://doi.org/10.1016/j.chb.2016.09.034

Ismagilova E., Slade, E., Rana, N. P., \& Dwidedi, K. Y. (2020). The effect of characteristics of source credibility on consumer behaviour: a meta-analysis. Journal of Retailing and Consumer Service, 53, 1-9. https://doi.org/10.1016/j.jretconser.2019.01.005

Jacoby, J., \& Kaplan, L. B. (1972). The components of perceived risk. Proceedings of the Third Annual Conference of the Association for Consumer Research, 10, 382-393.

Jiménez, F. R., \& Mendoza, N. A. (2013). Too popular to ignore: the influence of online reviews on purchase intentions of search and experience products. Journal of Interactive Marketing, 27(3), 226-235. https://doi.org/10.1016/j.intmar.2013.04.004

Kim, M., \& Lee, M. (2015). Effects of review characteristics and consumer regulatory focus on perceived review usefulness. Social Behavior and Personality, 43(8), 1319-1333.

https://doi.org/10.2224/sbp.2015.43.8.1319 
Kreutzer, R. T. (2015). Digitale revolution. Auswirkungen auf das Marketing. Springer. https://doi.org/10.1007/978-3-658-09394-5

Kreutzer, R. T. (2019). Online marketing (2nd ed.). Springer. https://doi.org/10.1007/978-3-658-25360-8

Ku, Y. C., Wei C. P., \& Hsiao, H. W. (2012). To whom should I listen? Finding reputable reviewers in opinion-sharing communities. Decision Support Systems, 53(3), 534-542. https://doi.org/10.1016/j.dss.2012.03.003

Kumashiro, M., Rusbult, C. E., Finkenauer, C., \& Stocker, S. L. (2007). To think or to do: The impact of assessment and locomotion orientation on the Michelangelo phenomenon. Journal of Social and Personal Relationships, 24(4), 591-611. https://doi.org/10.1177/0265407507079261

Lee, A. Y., \& Aaker, J. L. (2004). Bringing the frame into focus: the influence of regulatory fit on processing fluency and persuasion. Journal of Personality and Social Psychology, 86(2), 205-218. https://doi.org/10.1037/0022-3514.86.2.205

Lee, K.-T., \& Koo, D.-M. (2012). Effects of attribute and valence of e-WOM on message adoption: Moderating roles of subjective knowledge and regulatory focus. Computers in Human Behavior, 28(5), 1974-1984. https://doi.org/10.1016/j.chb.2012.05.018

Lin, T. M. Y., \& Fang, C.-H. (2006).The effects of perceived risk on the word-of-mouth communication dyad. Social Behavior and Personality: An International Journal, 34(10), 1207-1216. https://doi.org/10.2224/sbp.2006.34.10.1207

Lin, H.-F., \& Shen, F. (2012). Regulatory focus and attribute framing: Evidence of compatibility effects in advertising. International Journal of Advertising, 31, 169-188. https://doi.org/10.2501/IJA-31-1-169-188

Lis, B. \& Fischer, M. (2020). Analyzing different types of negative online consumer reviews. Journal of Product \& Brand Management, 29(5), 637-653. https://doi.org/10.1108/JPBM-05-2018-1876

Luo, H., Huang, W., Chen, C., Xie, K., \& Fan, Y. (2018, July). An empirical study on the impact of negative online word-of-mouth on consumer's purchase intention. In 15th International Conference on Service Systems and Service Management (ICSSSM) (pp. 1-6). IEEE. https://doi.org/10.1109/ICSSSM.2018.8465093

Nan, G., Yang, J., \& Dou, R. (2017). Do only review characteristics affect consumers' online behaviors? A study of relationship between reviews. Journal of Electronic Commerce Research, 18(4), 330-345.

Park, C., \& Lee, M. T. (2009). Antecedents of online reviews' usage and purchase influence: an empirical comparison of U.S. and Korean consumers. Journal of Interactive Marketing, 23(4), 332-340. https://doi.org/10.1016/j.intmar.2009.07.001

Park, C., Wang, Y., Yao, Y., \& Kang, Y. R. (2011). Factors influencing e-WOM effects: using experience, credibility and susceptibility. International Journal of Social Science and Humanity, 1(1), 74-79. https://doi.org/10.7763/IJSSH.2011.V1.13

Prendergast, G., Ko, D., \& Yuen, S. Y. V. (2010). Online word of mouth and consumer purchase intention. International Journal of Advertising, 29(5), 687-708. https://doi.org/10.2501/S0265048710201427

Shihab, M. R., \& Putri, A. (2019). Negative online reviews of popular products: understanding the effects of review proportion and quality on consumers' attitude and intention to buy. Electronic Commerce Research, 19(1), 159-187. https://doi.org/10.1007/s10660-018-9294-y

Schöler, A. (2010). Negative Mundpropaganda durch Beschwerden. In A. M. Schüller, \& T. Schwarz (Eds.), Leifaden WOM Marketing (pp. 375-388). Marketing-BÖRSE.

Steckel, J. H., Winer, R. S., Bucklin, R. E., Dellaert, B. G. C., Dreze, X., Haubl, G., Jap, S. D., Little, J. D. C., Meyvis, T., Montgomery, A. L., \& Rangaswamy, A. (2005). Choice in interactive environments. Marketing Letters, 16(3/4), 309-320. https://doi.org/10.1007/s11002-005-5894-0

Stone, R. N., \& Mason, B. J. (1995). Attitude and risk: exploring the relationship. Psychology and Marketing, 12(2), 135-153. https://doi.org/10.1002/mar.4220120205 
Strauss, B., \& Seidel, W. (2007). Complaint management, dissatisfied customers as beneficial target group (4th ed.). Hanser.

Thomas, M.-J., Wirtz, B. W., \& Weyerer, J. C. (2019). Determinants of online review credibility and its impact on consumers' purchase intention. Journal of Electronic Commerce Research, 20(1), 1-21.

Tian, L., \& Ren, G. (2009). Research on the perceived risk of consumer in e-business [Unpublished doctoral dissertation]. Beijing Union University, Beijing, China.

Tropp, J. (2019). Moderne Marketing-Kommunikation: Grundlagen, Prozess und Managementmarkt -und kundenorientierter Unternehmenskommunikation. Springer. https://doi.org/10.1007/978-3-658-25318-9

Van Noort, G., Kerkhof, P., \& Fennis, B. M. (2008). The persuasiveness of online safety cues: The impact of prevention focus compatibility of web content on consumers' risk perceptions, attitudes, and intentions. Journal of Interactive Marketing, 22, 58-72. https://doi.org/10.1002/dir.20121

Vellis, R. F. De (2003). Scale development: Theory and applications, (2 ${ }^{\text {nd }}$ ed.). Sage Publications.

Wetzer, I. M., Zeelenberg, M., \& Pieters, R. (2007). Never eat in that restaurant, I did: Exploring why people engage in negative word-of-mouth communication. Psychology and Marketing, 24(8), 661680. https://doi.org/10.1002/mar.20178

Zhang, J., Craciun, G., \& Shin, D. (2010). When does electronic word-of-mouth matter? A study of consumer product reviews. Journal of Business Research, 63(12), 1336-1341.

https://doi.org/10.1016/j.jbusres.2009.12.011 